\title{
Effects of Aging on Insulin Synthesis and Secretion

\author{
Differential Effects on Preproinsulin Messenger RNA Levels, Proinsulin Biosynthesis, \\ and Secretion of Newly Made and Preformed Insulin in the Rat
}

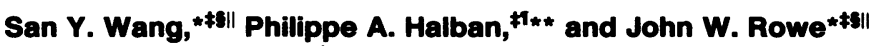

${ }^{*}$ Division on Aging, and ${ }^{\ddagger}$ Department of Medicine, Harvard Medical School, ${ }^{8}$ Gerontology Division, Joint Department of Medicine, Beth Israel and Brigham and Women's Hospitals, Charles A. Dana Research Institute and the Harvard Thorndike Laboratory, Beth Israel Hospital, "Geriatric Research Education Clinical Center, Brockton/West Roxbury Veterans Administration Medical Center, 'E. P. Joslin Research Laboratories, Joslin Diabetes Center, Boston, Massachusetts 02115; and **Unité Jeantet, Centre Médicale Universitaire, 1211 Geneva 4, Switzerland

\begin{abstract}
Aging in men and rodents is associated with a marked decline in glucose stimulated insulin secretion by pancreatic beta cells (B cells). Secreted insulin is the end result of a series of steps along the biosynthetic protein-secretion pathway, including insulin gene transcription, processing of transcripts to preproinsulin mRNA, translation of $m$ RNA, segregation and processing of newly made proinsulin in secretory vesicles, proinsulin to insulin conversion, transport of vesicles to the plasma membrane, and exocytosis. We have examined the influence of age at three stages along this pathway: preproinsulin mRNA levels, proinsulin synthesis, and secretion of newly made and preformed insulin, using Fischer rats, a widely studied rodent model of aging. Pancreatic weights and total insulin contents, islet sizes, and mean insulin content per islet were the same in young adult (4-5 mo) and senescent (21-22 mo) animals. There was no effect of age on preproinsulin mRNA levels in whole pancreata of fed animals, or in isolated islets cultured for $16 \mathrm{~h}$ in $5.5 \mathrm{mM}$ glucose. Proinsulin biosynthesis and the secretion of newly made insulin were compared in isolated islets preincubated in $5.5 \mathrm{mM}$ glucose. After a pulse label at $\mathbf{1 6 . 7}$ mM glucose, proinsulin synthesis, assayed by immunoprecipitation, was decreased 16\% in 7 mo islets and 39\% in 21-22 mo islets, compared with 4-5 mo islets, though total protein synthesis was not reduced. When chased at $2.8 \mathrm{mM}$ glucose, 4-5 month and 21-22 mo islets showed no difference in release of preformed or newly made insulin. When chased at $16.7 \mathrm{mM}$ glucose, there was a significant decrease in the secretion of newly made insulin in the old islets compared with the young islets. There was preferential release of newly made insulin over preformed insulin in both young and old islets. However, since secretion of preformed insulin was decreased much more than secretion of newly made insulin in senescent islets, these displayed a two- to threefold increase in the proportion of newly made insulin relative to total immunoreactive insulin released compared with young adult islets. The differential effects of aging on these steps in the insulin synthesis-secretion pathway may be due to varying impairments in signals
\end{abstract}

Address all correspondence to Dr. J. W. Rowe, Gerontology Division, Department of Medicine, SL-435, Beth Israel Hospital, Boston, MA 02215.

Received for publication 21 January 1987 and in revised form 24 August 1987.

The Journal of Clinical Investigation, Inc.

Volume 81, January 1988, 176-184 transducing the glucose stimulus into the wide range of $B$ cell responses to glucose.

\section{Introduction}

There is now considerable evidence that the development of overt non-insulin-dependent diabetes usually requires an impairment of pancreatic beta cell function as well as diminished effectiveness of insulin's action at its target tissues (1). Similarly, the glucose intolerance of aging, which is primarily due to a postreceptor defect in insulin-mediated glucose disposal (2-5), and accompanied by a decrease in insulin clearance (6), has been shown to be associated with defectiveness in the primary B cell function, glucose-stimulated insulin secretion (7-10). In particular, the Reavens and their collaborators have shown in rats that insulin secretion per B cell decreases with age, even if the animals are prevented from becoming obese by exercise or caloric restriction (8). Recently, Chen et al. have also found evidence of decreased $B$ cell responsiveness with age in man in vivo, by analyzing data from frequently sampled intravenous glucose tolerance tests with a minimal model approach, and independently by measuring plasma insulin response to glycemia with arginine potentiation (11).

Although aging's effects on insulin secretion have been extensively studied, its effects on the preceding stages along the insulin biosynthesis-transport-secretion pathway have not been investigated in detail. In the present experiments, we compared the total insulin content, islet number and islet insulin content, and preproinsulin mRNA levels in pancreata and isolated islets from young and old male Fischer rats. We also compared glucose-stimulated proinsulin biosynthesis by islets from young adult (4-5 mo), adult ( $7 \mathrm{mo}$ ), and senescent (21-22 mo) animals, and evaluated the secretion of newly made and preformed insulin in young adult and senescent animals. We found that total pancreatic insulin content and pancreatic preproinsulin mRNA levels did not change with age in the basal state in fed animals. In isolated islets, preproinsulin mRNA levels were the same in young and old islets preincubated for $16 \mathrm{~h}$ in $5.5 \mathrm{mM}$ glucose, but proinsulin biosynthesis after a pulse-label period at $16.7 \mathrm{mM}$ glucose was decreased with age, both per islet and as a percentage of preformed stores of insulin. Although newly made insulin was preferentially secreted by both young and old islets, glucose regulation of the release of newly synthesized insulin compared with that of preformed, stored insulin appeared to be differentially affected by age, with older animals secreting a higher percentage of newly made insulin. These findings suggest that decreased insulin synthesis and secretion in old islets are due to impaired transduction with age of the glucose stimu- 
lus into signals affecting posttranscriptional steps in the insulin secretory pathway.

\section{Methods}

Animals. Male, virgin F344/NHsd rats at 4, 6, and 20-21 mo of age were obtained from the National Institute on Aging barrier-reared, specific pathogen-free colonies maintained by Harlan Sprague Dawley, Inc., Indianapolis, IN, and were kept in single, suspended, wire-mesh cages in isolation cubicles for 1-4 wk before use. They were fed Formulab chow (Ralston-Purina Co., St. Louis, MO), a high energy, high protein complete life cycle diet, and water ad libitum, and maintained on a 12-h day-night cycle at $23 \pm 1^{\circ} \mathrm{C}$. Animals were routinely sacrificed at 10 a.m., i.e., $\sim 4 \mathrm{~h}$ into the day cycle. All old animals used in these experiments appeared healthy, and were free of gross pathological abnormalities on examination at necropsy, other than the testicular interstitial tumors characteristically found in old males of this strain.

Preparation of pancreatic and islet RNA and measurement of insulin $m R N A$. For preparation of pancreatic RNA, pancreata were dissected out, weighed, and a portion homogenized and extracted overnight in acid-alcohol for measurement of insulin content. The remainder was homogenized in $15 \mathrm{ml}$ per pancreas of freshly prepared guanidinium isothiocyanate, and purified by four cycles of suspension in guanidine- $\mathrm{HCl}$ and ethanol precipitation (12). The total RNA was precipitated twice more with sodium acetate and ethanol, and resuspended in water at $1-2 \mathrm{mg} / \mathrm{ml}$. To ensure an accurate measurement of RNA concentration for gel electrophoresis, $15 \mu \mathrm{l}$ of the concentrated RNA was aliquoted into a microfuge tube, and $5 \mu \mathrm{l}$ of this diluted into $1 \mathrm{ml}$ of water for $O D_{260 / 280}$ readings and measurement of RNA concentration by the orcinol reaction. The remaining $10 \mu l$ were used for preparation of sample for gel electrophoresis. The total RNA was fractionated on $1 \%$ agarose-formaldehyde gels (13); 2-4 $\mu \mathrm{g}$ of total pancreatic RNA from young and old animals, as assessed by $O D_{260}$ readings and orcinol measurements, were analyzed simultaneously, and a set of dilutions from 0.75 to $4.5 \mu \mathrm{g}$ of a standard preparation of total pancreatic RNA from a 4-mo rat was loaded on the same gel. After electrophoresis, RNA was transferred by capillary blotting onto nitrocellulose filters (HAHY; Millipore/Continental Water Systems, Bedford, MA). The RNA was hybridized to nick translated $\left[\alpha{ }^{32} \mathrm{P}\right] \mathrm{dCTP}(800 \mathrm{Ci} /$ mmol; New England Nuclear, Boston, MA) or $\left[\alpha^{32}\right.$ S $]$ dCTP $(1,100$ $\mathrm{Ci} / \mathrm{mmol}$, New England Nuclear)-labeled rat preproinsulin I cDNA in $50 \%$ formamide, $10 \%$ dextran sulfate for $20 \mathrm{~h}$ at $42^{\circ} \mathrm{C}$. Hybridized filters were washed, dried, and autoradiographed with Kodak X-Omat AR film at $-70^{\circ} \mathrm{C}$. Autoradiograms were scanned with an integrating densitometer (Joyce Loebl; Haake Buchler Instruments, Inc., Saddle Brook, NJ). Within the range of insulin mRNA used, densitometry readings were linear with amount of total RNA loaded, as assessed by densitometry of dilutions of the standard RNA preparation, so that differences in content of insulin mRNA between old and young total pancreatic RNA could be compared by simple linear extrapolation.

Recovery of RNA from isolated islets using the above guanidinium isothiocyanate technique was unsatisfactory, so an alternative procedure was used. This procedure has been shown to yield $>90 \%$ recovery of poly(A) RNA (14). Islets were washed twice in Hanks' salts with glucose and $2.5 \mathrm{mg} / \mathrm{ml}$ human serum albumin, fraction $\mathrm{V}$ (HSA, ${ }^{1}$ Sigma Chemical Co., St. Louis, MO), in $12 \times 75 \mathrm{~mm}$ polypropylene tubes, and an aliquot of islets sonicated in $0.2 \mathrm{M}$ glycine, $\mathrm{pH} \mathrm{8.8,2.5}$ $\mathrm{mg} / \mathrm{ml} \mathrm{HSA}, 0.5 \% \mathrm{NP}-40$ for measurement of insulin content by radioimmunoassay. To another aliquot of 50 islets, $400 \mu$ of TEN $(0.01 \mathrm{M}$ Tris- $\mathrm{HCl}, \mathrm{pH} 7.5,0.025 \mathrm{M}$ EDTA, $0.1 \mathrm{M} \mathrm{NaCl}$ ) containing $0.5 \%$ SDS, $0.1 \mathrm{M} \beta$-mercaptoethanol, and $100 \mu \mathrm{g} / \mathrm{ml}$ proteinase $\mathrm{K}$ (Boehringer Mannheim Biochemicals, Indianapolis, IN) were added. Immediately

1. Abbreviations used in this paper: HSA, human serum albumin; TEN, $0.01 \mathrm{M}$ Tris- $\mathrm{HCl}, \mathrm{pH} 7.5,0.025 \mathrm{M}$ EDTA, $0.1 \mathrm{M} \mathrm{NaCl}$; TCA, trichloroacetic acid. thereafter, another $400 \mu \mathrm{l}$ of phenol/chloroform/isoamyl alcohol (100:99:1, vol/vol/vol) containing $0.1 \%$ 8-hydroxyquinoline were added at room temperature (the phenol previously saturated with TEN). The mixture was sonicated for $15 \mathrm{~s}$ and centrifuged for $10 \mathrm{~min}$. The organic phase was reextracted with $100 \mu l$ of TEN, and the combined aqueous phases extracted three more times at room temperature with $500 \mu \mathrm{l}$ of phenol/chloroform and twice with $500 \mu \mathrm{l}$ of chloroform/isoamyl alcohol alone. The final aqueous phase was made $0.4 \mathrm{M}$

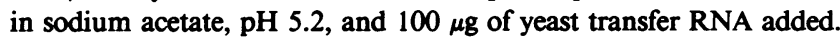
RNA was precipitated with $2.5 \mathrm{vol}$ of ethanol for $12 \mathrm{~h}$ at $-20^{\circ} \mathrm{C}$. The precipitate was pelleted in a microfuge, dissolved in $200 \mu \mathrm{l}$ of water, readjusted to $0.4 \mathrm{M}$ sodium acetate, and reprecipitated. The final pellet was dried briefly in a vacuum oven at room temperature, and dissolved in $30 \mu \mathrm{l}$ of loading buffer for electrophoresis. Islet RNA was fractionated on $1 \%$ agarose-formaldehyde gels, transferred to filters, and hybridized as described above.

The probe used for hybridization, pcr(I)IN, which comprises the coding region of rat preproinsulin I inserted into the Hind III site of pBR322, was constructed by Ullrich et al. (15), and kindly given to us by Dr. Howard Goodman, Department of Molecular Biology, Massachusetts General Hospital, Boston, MA. Plasmid DNA was prepared by alkali lysis of bacterial pellets, and centrifugation of DNA to equilibrium in cesium chloride-ethidium bromide gradients (13). The intact plasmid DNA was used, since its background hybridization to 4 and 22 mo rat liver total RNA was insignificant under our conditions. The rat preproinsulin I cDNA probe is $92 \%$ homologous to rat preproinsulin II mRNA (16), and in the present experiments, both rat I and rat II preproinsulin mRNA molecules were measured and not distinguished.

Preparation of islets and pulse-chase labeling. Islets were prepared by collagenase (type CLS IV; Cooper Biomedical, Inc., Malvern, PA) digestion of pancreata distended through the common bile duct, and separated from acinar tissue by banding on a discontinuous Ficoll gradient and picking of islets under a dissecting microscope $(17,18)$. The islets were incubated overnight in MEM with $10 \%$ calf serum (Flow Laboratories, McLean, VA) and $5.5 \mathrm{mM}$ glucose. After $16 \mathrm{~h}$, the major and minor axes of the islets were measured with an ocular micrometer, and the islets washed in Hanks' salts with $5.5 \mathrm{mM}$ glucose and $2.5 \mathrm{mg} / \mathrm{ml} \mathrm{HSA}$. Aliquots of 20 islets were dispensed into $12 \times 75$ $\mathrm{mm}$ polystyrene tubes, and pulse labeled for $30 \mathrm{~min}$ in $100 \mu \mathrm{l}$ of MEM (without leucine) with $10 \mathrm{mM}$ Hepes, $\mathrm{pH} 7.4,40 \mu \mathrm{Ci}$ of $\left[2,3,4,5-{ }^{3} \mathrm{H}\right]$ L-leucine (1 $10 \mathrm{Ci} / \mathrm{mmol}$; ICN Radiochemicals, Irvine, CA) (final leucine concentration $4 \mu \mathrm{M}$ ), and $16.7 \mathrm{mM}$ glucose, at $37^{\circ} \mathrm{C}$ in a shaking water bath. They were then washed four times with $2 \mathrm{ml}$ of MEM (containing $0.4 \mathrm{mM}$ unlabeled leucine) with Hepes, $2.5 \mathrm{mg} / \mathrm{ml} \mathrm{HSA}$, and either 2.8 or $16.7 \mathrm{mM}$ glucose, and then chased with $1 \mathrm{ml}$ of this medium. During the pulse and chase, the reaction tubes were gassed with $5 \% \mathrm{CO}_{2}, 95 \% \mathrm{O}_{2}$. Aliquots of $250 \mu \mathrm{l}$ were taken after $60,120,180$, and $240 \mathrm{~min}$, clarified at $4^{\circ} \mathrm{C}$ by spinning for $15 \mathrm{~min}$ at $10,000 \mathrm{rpm}$ in a microcentrifuge, and stored at $-20^{\circ} \mathrm{C}$. The pulsed islets and the islets after the 240-min chase period were frozen overnight in $1 \mathrm{ml}$ of $0.2 \mathrm{M}$ glycine, $\mathrm{pH} 8.8,2.5 \mathrm{mg} / \mathrm{ml} \mathrm{HSA}, 0.5 \% \mathrm{NP}-40$; thawed; sonicated; clarified in a microcentrifuge; and stored at $-20^{\circ} \mathrm{C}$.

Analysis of proinsulin-insulin biosynthesis. Proinsulin-insulin biosynthesis was analyzed by immunoprecipitation with antiinsulin serum and separation of immune complexes with protein A-Sepharose CL-4B (Pharmacia Fine Chemicals, Piscataway, NJ) as described previously (19). Titration with porcine insulin demonstrated that the lot of guinea pig antiinsulin serum (ICN ImmunoBiologicals, Lisle, IL) used could precipitate at least $30-50$-fold as much insulin as was present in the most insulin-rich experimental samples, and thus should also have precipitated proinsulin quantitatively. For some samples, labeled proinsulin and insulin were separated and quantitated by HPLC, as described in detail (20). Total insulin contents of islets, media, and pancreata were determined by charcoal-dextran radioimmunoassay (21), using rat insulin standards (courtesy of Eli Lilly and Co., Indianapolis, IN) and guinea pig anti-rat insulin serum (a generous gift of Dr. Gordon Weir, Joslin Diabetes Center, Boston, MA). Total protein synthesis was determined by mixing 10-20 $\mu$ l sample 
aliquots with $0.5 \mathrm{ml}$ of phosphate buffered saline containing $2.5 \mathrm{mg} / \mathrm{ml}$ of HSA, and adding $500 \mu \mathrm{l}$ of $10 \%$ trichloroacetic acid (TCA). The amount of radioactivity precipitated by TCA was then determined. Corrections were made for quenching differences in counts of samples assayed by immunoprecipitation and by TCA precipitation.

Data and statistics. Data are presented as means \pm SEM. The level of significance for differences of means of insulin biosynthetic parameters between young and old animals was evaluated by Student's unpaired, two-tailed $t$ tests (22).

\section{Results}

\section{Pancreatic islets and insulin content}

Under our standard animal care conditions, the mean body weight ( \pm SEM) for 4-5 mo virgin male Fischer rats was $319 \pm 10 \mathrm{~g}$ and for $21-22$ mo animals, $420 \pm 16 \mathrm{~g}$, a $32 \%$ increase $(P<0.001)$ that is characteristic of this strain. Rather surprisingly, the mean wet weights of the pancreata of 4-5 mo and $21-22$ mo rats were not different $(0.920 \pm 0.047$ vs. $0.923 \pm 0.047 \mathrm{~g}$ ), despite the $32 \%$ greater body weight of the older animals. Likewise, the total RNA contents of the old and young pancreata were not significantly different (Table I). Total pancreatic insulin content was the same in the young and old animals $(217 \pm 24$ vs. $245 \pm 10 \mu \mathrm{g})$. The mean insulin content of islets isolated from young and old animals was also similar ( $34.5 \pm 7.1$ vs. $37.9 \pm 6.7 \mathrm{ng} /$ islet). Assuming that the insulin content of isolated islets is the same as that of islets in vivo, one can calculate that there were 5,000-8,000 islets per pancreas in both the young and old animals.

Isolated islets varied greatly in size, with averaged diameters ranging from $60-190 \mu \mathrm{m}$. Fig. 1 compares histograms of islet sizes after $16 \mathrm{~h}$ incubation in MEM with $5.5 \mathrm{mM}$ glucose from young and old animals. The young animals had a larger proportion of small islets, and the old animals had a few very large islets not found in younger animals. Unlike a previous study of perifused islets (7), we did not find any differences in insulin secretion or synthesis between small and large islets in pilot studies, when results were normalized to total nanograms of insulin in the islets, and we used random aliquots of pooled islets in the studies reported here.

\section{Pancreatic and islet preproinsulin $m R N A$ levels}

We examined preproinsulin mRNA levels from whole pancreata of young and old rats in the fed state as an index of basal levels in islets in vivo, since young and old animals had similar total number of islets in their pancreata. We measured preproinsulin mRNA levels by densitometry of autoradiograms of Northern blots of total pancreatic RNA hybridized to a cDNA probe to rat preproinsulin I mRNA, which is also $>90 \%$ homologous to rat preproinsulin II mRNA. Fig. 2 shows a representative Northern blot. There was no difference

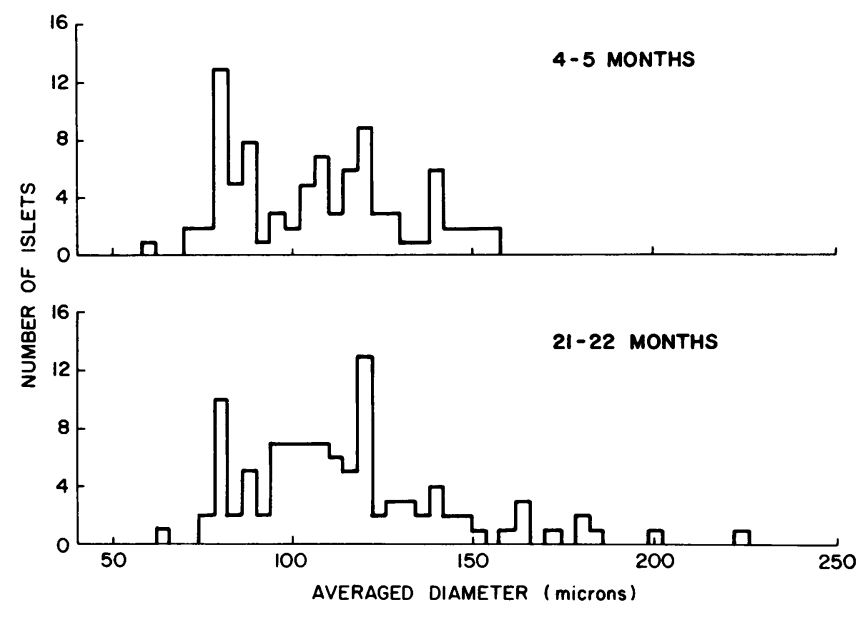

Figure 1. Histograms of pancreatic islet sizes. Islets from 4-5- and 21-22-mo Fischer rats were isolated by collagenase digestion. After incubation for $16 \mathrm{~h}$ in MEM with $10 \%$ calf serum and $5.5 \mathrm{mM}$ glucose, islet diameters were measured as the average of lengths of major and minor axes. The islets were assumed to be elliptical.

between the young and old animals in content of insulin mRNA per microgram of total pancreatic insulin (Table II, column 1), or in the size of the mature preproinsulin mRNA molecules (Fig. 2).

Although pancreatic preproinsulin mRNA levels in vivo were the same in young and old animals, this might not be true of isolated islets, since these lose much of their preproinsulin mRNA content during the $1 \mathrm{st} 24 \mathrm{~h}$ of culture in vitro, particularly when maintained in low glucose (23-25). Further, old and young islets might have different rates of synthesis or degradation of preproinsulin mRNA during incubation in vitro at the same glucose concentration. Since we were interested in comparing insulin synthesis in isolated islets, we also measured insulin mRNA levels in islets. Because we measured proinsulin synthesis in islets after a recovery period after isolation, isolated islets were preincubated for $16 \mathrm{~h}$ in MEM with $5.5 \mathrm{mM}$ glucose and $10 \%$ calf serum, the same recovery conditions we used before measuring proinsulin synthesis, and total RNA was then extracted. Preproinsulin mRNA levels in the young and old islets were assessed by densitometry of autoradiograms of Northern blots of total islet RNA hybridized to rat preproinsulin I cDNA. As shown in Table II (colum 2), there was no significant difference in preproinsulin mRNA levels in the young and old islets.

\section{Proinsulin synthesis}

Islets isolated by collagenase digestion and banding on a Ficoll step gradient were allowed to recover from the isolation pro-

Table I. General Parameters Relevant to Insulin Biosynthesis in Young and Old Rats

\begin{tabular}{llllll}
\hline Age $(n)$ & Weight & Pancreas weight & $\begin{array}{l}\text { Pancreatic } \\
\text { insulin content }\end{array}$ & $\begin{array}{l}\text { Pancreatic } \\
\text { total RNA content }\end{array}$ & Islet insulin content \\
\hline$m o$ & $g$ & $g$ & $\mu g$ & $m g$ & $n g /$ islet \\
$4-5(5)$ & $319 \pm 10$ & $0.920 \pm 0.047$ & $217 \pm 24$ & $7.73 \pm 0.58$ & $34.5 \pm 7.1$ \\
$7(3)$ & $388 \pm 14$ & - & - & - & - \\
$21-22(5)$ & $420 \pm 16$ & $0.923 \pm 0.047$ & $245 \pm 10$ & $9.14 \pm 1.17$ & $37.9 \pm 6.7$ \\
\hline
\end{tabular}




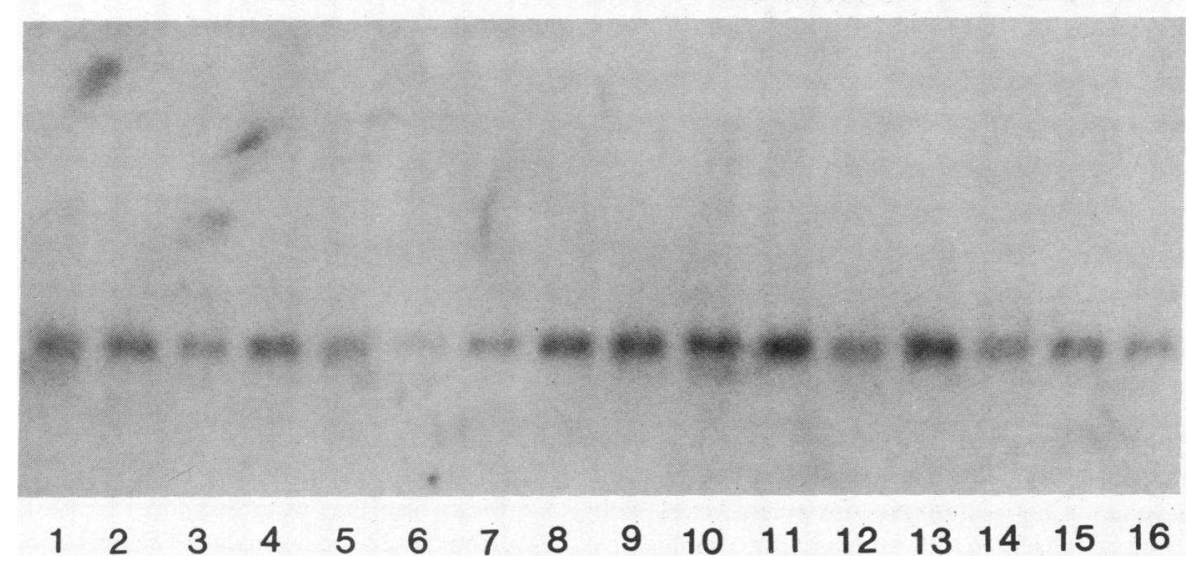

Figure 2. Northern blot of total pancreatic RNA from young and old Fischer rats.

Total pancreatic RNA was hybridized to ${ }^{32}$ P-labeled pcr(I)IN containing rat I preproinsulin cDNA. 2-4 $\mu \mathrm{g}$ of total pancreatic RNA was run in each well of a $1 \%$ agarose formaldehyde gel. Lanes 1-5, samples from five individual 4-5-mo animals. Lanes $12-16$, samples from five individual 21-22-mo animals. Lanes 6-11, dilutions from $0.75-4.5 \mu \mathrm{g}$ of a standard preparation of total pancreatic RNA from a 4-mo animal, to demonstrate linearity of band densities over the range of preproinsulin mRNA loaded in the old and young samples to be compared. cedure by incubation for $16 \mathrm{~h}$ in MEM with $10 \%$ calf serum. Preliminary studies showed that this recovery period led to much greater incorporation of labeled leucine subsequently. Islets were then pulse labeled for $30 \mathrm{~min}$ in MEM with 16.7 $\mathrm{mM}$ glucose and chased for $240 \mathrm{~min}$ in MEM with either 2.8 or $16.7 \mathrm{mM}$ glucose. The secretion of total insulin by the islets during the chase period, monitored by radioimmunoassay, is shown in Fig. 3. Both young and old islets secreted very little insulin at $2.8 \mathrm{mM}$ glucose (3\% vs. $2.5 \%$ of total islet insulin content over $240 \mathrm{~min}$ ). However, at $16.7 \mathrm{mM}$ glucose, the young islets secreted $29.2 \pm 2.5 \%$ of their total insulin content over $240 \mathrm{~min}$, a tenfold increase, whereas the old islets secreted $9.8 \pm 1.0 \%$, a fourfold increase.

After a 30-min pulse label, the specific radioactivity of immunoprecipitable material (which would be only proinsulin at this time) in the $4-5$-mo islets was $80.7 \pm 9.2$ vs. $49.0 \pm 2.3$ (counts per minute per nanogram of islet insulin) in the 21-22-mo islets (Table III). Assuming that the specific radioactivity of the leucine pool available for protein synthesis was the same in the young and old islets, this would mean that the old islets made $39 \%$ less proinsulin during the pulse since young and old islets had similar stores of preformed insulin.
This assumption is supported by the finding that islet total protein synthesis, measured as TCA-precipitable leucine radioactivity, and expressed per nanogram of islet insulin, was similar in young and old islets (Table III, column 2). Further, there was no difference in the amount of free leucine in young and old islets, as assessed by non-TCA-precipitable islet radioactivity (Table III, column 3). These data strongly support the conclusion that the specific radioactivity of leucine was the same in the young and old islets, and hence that the absolute differences in $\left[{ }^{3} \mathrm{H}\right]$ leucine incorporated into proinsulin between young and old islets reflected actual differences in synthesis, rather than intra-B cell leucine pool size changes.

The ratio of labeled proinsulin to labeled total protein after a pulse-label period at $16.7 \mathrm{mM}$ glucose was also examined. This ratio is independent of changes in leucine pool specific activity, and was $0.268 \pm 0.008$ in the $4-5-\mathrm{mo}$ animals and $0.167 \pm 0.018$ in the $21-22-\mathrm{mo}$ animals, a $38 \%$ decrease. Therefore, the old islets not only made less proinsulin at $16.7 \mathrm{mM}$ glucose, but also made less proinsulin as a fraction of total protein synthesis.

It was conceivable that the decrease in proinsulin synthesis seen in the 21-22-mo animals was solely secondary to islet
Table II. Preproinsulin mRNA Content in Whole Pancreas and Isolated Islets

\begin{tabular}{lll}
\hline Age & $\begin{array}{l}\text { Whole pancreatic } \\
\text { preproinsulin mRNA content } \\
\text { per microgram of insulin }(n)^{*}\end{array}$ & $\begin{array}{l}\text { Isolated islet preproinsulin } \\
\text { mRNA content per } \\
\text { nanogram of insulin }(n)\end{array}$ \\
\hline$m o$ & $U / \mu g$ & $U / n g$ \\
$4-5$ & $3.73 \pm 0.53(5)$ & $3.42 \pm 0.78(3)$ \\
$21-22$ & $3.45 \pm 0.55(5)$ & $\begin{array}{l}3.39 \pm 0.65(4) \\
P=N S\end{array}$ \\
& $P=N S$ & $P=\mathrm{NS}$
\end{tabular}

$P$ values are for comparisons of 4-5- and 21-22-mo animals.

* Whole pancreatic and isolated islet preproinsulin mRNA contents are expressed in arbitrary units, reflecting the integrals of band densities in autoradiograms. Band densities increased linearly with amounts of RNA loaded for the range of amounts of RNA used in these Northern blots. Islet preproinsulin mRNA content was measured in islets preincubated for $16 \mathrm{~h}$ in MEM with $5.5 \mathrm{mM}$ glucose. Since whole pancreatic and isolated islet preproinsulin mRNA levels were measured in separate hybridization experiments, the values in column 1 have no direct correlation with those in column 2 .

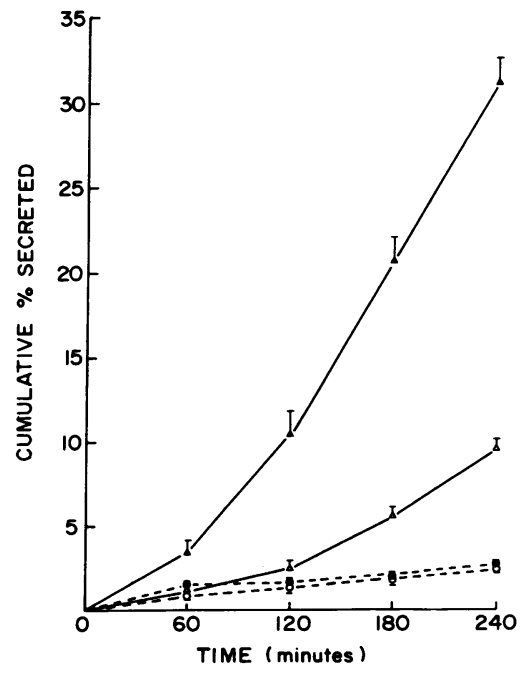

Figure 3. Secretion of insulin by young and old islets at $2.8 \mathrm{mM}$ (young [-- --$]$, old $[--0--])$ and 16.7 mM (young [ $\triangle-$ ], old $[-\Delta-])$ glucose. After preincubation for $16 \mathrm{~h}$ in MEM, batches of 20-30 islets were incubated for $30 \mathrm{~min}$ in $16.7 \mathrm{mM}$ glucose, washed, and then chased for $240 \mathrm{~min}$ in 2.8 or $16.7 \mathrm{mM}$ glucose. Insulin secreted during the chase was measured by radioimmunoassay. The secretion results are given as percent of islet insulin content at the start of the chase; islet insulin content measured at the end of the chase was unchanged. 
Table III. Effects of Age on Incorporation of $\left[{ }^{3} \mathrm{H}\right]$ Leucine into Proinsulin and Total Protein by Islets after a 30-min Pulse Label at $16.7 \mathrm{mM}$ Glucose (Islets Were Preincubated for $16 \mathrm{~h}$ in MEM with $5.5 \mathrm{mM}$ Glucose)

\begin{tabular}{lllll}
\hline Age $(n)$ & Proinsulin & Total protein & Free leucine & \multicolumn{1}{c}{ Labeling ratio* } \\
\hline mo & cpm/ng islet insulin & cpm/ng islet insulin & cpm/ng islet insulin & \\
$4-5(5)$ & $80.7 \pm 9.2$ & $285.7 \pm 27.8$ & $27.2 \pm 5.0$ & $0.268 \pm 0.008$ \\
$7(3)$ & $68.0 \pm 11.6$ & $250.9 \pm 42.9$ & $35.1 \pm 7.1$ & $0.223 \pm 0.017$ \\
$21-22(5)$ & $49.0 \pm 2.3$ & $256.7 \pm 42.7$ & $25.8 \pm 4.2$ & $0.167 \pm 0.018$ \\
& $P<0.01$ & NS & NS & $P<0.01$
\end{tabular}

Proinsulin and total protein synthesis were measured in the same islets, the former by immunoprecipitation and the latter by incorporation into TCA-precipitable products; free leucine is taken as the non-TCA-precipitable, intraislet radioactivity. Results are expressed as counts per minute per nanogram of islet insulin. Islet insulin contents for islets preincubated in MEM with $5.5 \mathrm{mM}$ glucose that were 4-5 mo 39.2 \pm 4.0 ng/islet, $7 \mathrm{mo} 29.5 \pm 2.9 \mathrm{ng} /$ islet, and 21-22 mo $37.5 \pm 6.0 \mathrm{ng} /$ islet. $P$ values are for comparisons of 4-5- and 21-22-mo animals. ${ }^{*}$ Counts per minute in immunoprecipitable proinsulin per counts per minute in TCA-precipitable protein.

dysfunction brought on by the $32 \%$ increased weight of the older animals. We examined insulin synthesis in a group of 7-mo animals as well. As shown in Table I, their weights were only $7 \%$ less than that of the 21-22-mo animals. Synthesis of proinsulin, as reflected by specific radioactivity of proinsulin and proinsulin-total protein labeling ratio, was intermediate between that of 4-5- and 21-22-mo animals (Table III). Thus, proinsulin biosynthesis is already somewhat impaired in the 7-mo animals, but not to the extent of the 21-22-mo animals, and the additional decrease from 7 to $21-22$ mo was primarily associated with age, although increased weight might also have contributed. The progressive decline in proinsulin biosynthesis throughout the age range studied also supports the inference that this decrease is truly an effect of aging, and not the result of comparing a stage of growth and development to one of senescence (26).

\section{Secretion of newly made insulin}

The secretion of newly made insulin from islets (preincubated in vitro for $16 \mathrm{~h}$ in MEM with $5.5 \mathrm{mM}$ glucose) was examined over $240 \mathrm{~min}$ chase periods in 2.8 and $16.7 \mathrm{mM}$ glucose, after a 30-min pulse-label period in $16.7 \mathrm{mM}$ glucose, by measuring the radioactivity of secreted insulin sampled every $60 \mathrm{~min}$. Two considerations need to be raised here. The first is the effectiveness of the washout of labeled leucine from the pulse period before the start of the chase. If washout of labeled leucine from the intraislet leucine pool was inefficient, more labeled proinsulin could be synthesized during the early part of the chase, and make the secretion of newly synthesized insulin difficult to assess accurately. However, we found that after four washes of the pulsed islets in MEM with $0.4 \mathrm{mM}$ unlabled leucine, only $3-8 \%$ of the labeled intraislet leucine remained non-TCA precipitable, and hence in the free leucine pool (data not shown), and the values were similar for young and old islets. This small amount of residual-labeled leucine at the start of the chase would not have had any significant effect on our results.

The second consideration in interpreting these pulse-chase experiments is that while all insulin-specific immunoprecipitable radioactivity after a 30 -min pulse is proinsulin, most of the secreted insulin during the chase is insulin; thus, a correction had to be made to take into account the loss of radioactivity in secreted C-peptide, which is not immunoprecipitated in the assay system. Samples of secreted $\left[{ }^{3} \mathrm{H}\right]$ leucine-labeled ma- terial from 7 and 24 mo islets were taken after a 120-min chase and fractionated by HPLC; in general, they showed a $10-20 \%$ ratio of label in proinsulin vs. insulin, which is similar to values for islets from young animals (20). Gold et al. (27) have also reported that young and old islets secrete similar ratios of labeled proinsulin and insulin in pulse-chase experiments at $25 \mathrm{mM}$ glucose. We took $15 \%$ as an average proinsulin/insulin ratio, and corrected the specific activity of the insulin secreted during the chase using this factor. ${ }^{2}$

Table IV shows the effects of age on the amounts of total immunoreactive insulin and labeled insulin and protein secreted over the entire 240 -min chase period in $2.8 \mathrm{mM}$ glucose, and the percentages of labeled insulin, protein, and total immunoreactive insulin present after the 30 -min pulse period that were secreted in the subsequent chase period. There was no significant difference in the amount of percent secretion of newly made or preformed insulin between young and old islets over the chase period. To follow the time course of secretion of newly made insulin and its relative contribution to total insulin secretion over the chase, secreted immunoprecipitable-labeled insulin was determined at 60 -min intervals during the chase. Total secreted immunoreactive insulin was also measured by radioimmunoassay, and the specific radioactiviy of secreted insulin (counts per minute of secreted insulin per nanogram of total immunoreactive insulin) calculated. The data at each time point were then normalized to the specific radioactivity of newly made intraislet insulin after the 30 -min pulse period. Fig. $4 \mathrm{~A}$ shows the time course of secretion of newly made insulin by young and old islets at 60 -min intervals during a chase at $2.8 \mathrm{mM}$ glucose. One can see that the peak specific activity of secreted insulin occurred at the 120 -min sample for both old and young islets, implying that newly made insulin formed the greatest proportion of secreted insulin at this time. There was no significant difference in specific radioactivity of secreted insulin between young and old islets at any of the time points; thus, the time course of secretion of newly made insulin was the same.

2. 24-mo islets chased at $2.8 \mathrm{mM}$ glucose may have secreted a higher ratio of proinsulin to insulin; the small amount of labeled hormone secreted made accurate determination of the ratio difficult, and possibly influenced by a small fraction of degenerating islets. However, even much higher ratios would not have substantially affected the trend shown in Fig. 4 for old islets. 
Table IV. Effects of Age on Secretion of Total Immunoreactive Insulin and ${ }^{3}$ H-Labeled Insulin and Protein by Islets over a 240-min Chase Period at $2.8 \mathrm{mM}$ Glucose After a 30-min Pulse-Label Period (Islets Were Preincubated for 16 in MEM with 5.5 mM Glucose)

\begin{tabular}{|c|c|c|c|c|c|}
\hline \multirow[b]{2}{*}{ Age } & \multicolumn{2}{|c|}{ Amount secreted in $2.8 \mathrm{mM}$ chase } & \multicolumn{3}{|c|}{ Secreted in $2.8 \mathrm{mM}$ chase } \\
\hline & {$\left[{ }^{3} \mathrm{H}\right] \mathrm{INS}$} & {$\left[{ }^{3} \mathrm{H}\right]$ PROT } & {$\left[{ }^{3} \mathrm{H}\right] \mathrm{INS}$} & RIA INS & {$\left[{ }^{3} \mathrm{H}\right] \mathrm{PROT}$} \\
\hline mo & cpm/ng islet insulin & cpm/ng islet insulin & $\%$ & $\%$ & $\%$ \\
\hline $4-5$ & $1.4 \pm 0.7$ & $13.1 \pm 1.0$ & $6.2 \pm 2.1$ & $3.0 \pm 0.5$ & $5.8 \pm 0.7$ \\
\hline $21-22$ & $0.5 \pm 0.4$ & $10.3 \pm 0.6$ & $5.0 \pm 1.7$ & $2.5 \pm 0.5$ & $7.0 \pm 1.2$ \\
\hline$n$ & 4 & 4 & 4 & 4 & 4 \\
\hline$P$ & NS & NS & NS & NS & NS \\
\hline
\end{tabular}

Islets were pulse-labeled for $30 \mathrm{~min}$ in $16.7 \mathrm{mM}$ glucose with [ $\left.{ }^{3} \mathrm{H}\right]$ leucine, and then subjected to a 240 -min chase period in the presence of 2.8 $\mathrm{mM}$ glucose. The secretion of total immunoreactive insulin (RIA INS) was measured by radioimmunoassay. The secretion of labeled insulin $\left(\left[{ }^{3} \mathrm{H}\right] \mathrm{INS}\right)$ was measured by immunoprecipitation, correcting the measured immunoprecipitated counts per minute, a mixture of insulin and proinsulin, to equivalent amounts of insulin by assuming that $15 \%$ of the secreted, immunoprecipitated counts per minute was proinsulin (see Results). The secretion of labeled total protein $\left(\left[{ }^{3} \mathrm{H}\right] \mathrm{PROT}\right)$ was measured by TCA precipitation of labeled, secreted products. Results for "amount secreted" columns are expressed as counts per minute per nanogram of islet insulin. Results for "Secreted" columns are expressed as percent of intraislet content after the 30-min pulse-label period that was secreted in the subsequent 240 -min chase period. The labeling of proinsulin was less efficient for this set of experiments than for the set presented in Table III: $57.0 \pm 12.9 \mathrm{cpm} / \mathrm{ng}$ of islet insulin for the young islets, and $24.1 \pm 10.1 \mathrm{cpm} / \mathrm{ng}$ of islet insulin for the old islets. The number of separate experiments $(n)$ is shown in parentheses. $P$ values are for comparisons of 4-5- and 21-22-mo animals.

When the chase was done at $16.7 \mathrm{mM}$ glucose, young and old islets showed significant differences. The absolute amount of newly made insulin secreted over the 240-min chase period by old islets decreased $64 \%$ (Table V). The percent of newly made insulin that was secreted was also significantly different between young and old islets $(61.9 \pm 5.3 \%$ vs. $36.2 \pm 2.4 \%, P$ $<0.01$ ). Because the percent of intraislet total immunoreactive insulin (mostly preformed, unlabeled insulin) that was secreted was markedly decreased in the old islets $(29.5 \pm 2.5 \%$ vs. $9.8 \pm 1.0 \%$ ), there was a 2.3 -fold increase in the relative proportion of total insulin secreted over the 240-min chase period by old islets that was newly made compared with the proportion in young islets. When the time course of secretion of newly made insulin and its relative contribution to total insulin secretion was calculated, as described for the $2.8 \mathrm{mM}$ glucose chase, one can see (Fig. $4 B$ ) that the normalized specific radioactivity of secreted insulin at 120 min was 3.5 times higher in the old islets compared with the young islets $(12.2 \pm 2.05$ vs. $3.45 \pm 0.30, P<0.01)$, so that newly made insulin made up a much greater proportion of the secreted insulin from old islets at this time. In fact, this was true for all the chase time points except the last.

It should be emphasized that the overall secretion of both newly made and total, largely preformed, immunoreactive insulin was decreased in old islets. However, the relative contribution of newly made insulin to the secreted insulin was greatly increased in old islets because, while there was a large decrease in secretion of preformed insulin over the chase period in old islets compared with young islets, secretion of newly made insulin was affected considerably less.

\section{Discussion}

We examined the effects of aging on two essential aspects of pancreatic beta cell function, glucose-stimulated insulin biosynthesis and secretion of newly made insulin, which have previously been explored only indirectly. We chose male Fischer 344 rats as our experimental animals, because they are a well characterized rodent model of aging, and their defects in glucose homeostasis parallel those in man. Thus, old Fischer rats have been shown to have similar fasting serum glucose values compared with young ones, but decreased glucose disappearance rates after an intravenous glucose tolerance test (28). Old animals have defective insulin secretion in the perfused pancreas (9), and in isolated islets $(29,30)$, and they have insulin resistance, manifested as multiple defects, after receptor binding, in glucose transport and glucose metabolism in ioslated adipocytes (28). Further, unlike many strains of rats, Fischer rats do not become massively obese as they age. Previous studies on Sprague-Dawley rats have shown large increases in pancreatic size, insulin content, islet size, and islet insulin content with age (27); these increases may be due to the doubling in weight of the older animals in this strain, changes that can be prevented by caloric restriction or exercise (8). We found that, although the male Fischer rats studied had a $32 \%$ weight gain between 4 and 5 mo and 21 and 22 mo, their pancreatic insulin content, average islet size and insulin content, and estimated number of islets per pancreas did not change.

We and others (2-4) have demonstrated a significant postreceptor defect in insulin-mediated glucose disposal with age in humans, and, as noted above, this has also been found in rats $(8,28)$. An increase in $B$ cell synthesis and secretion of insulin by old islets might compensate for this defect in insulin action at its target tissues, but this was not found to be the case.

Studies of insulin synthesis and secretion by isolated islets showed that old islets were impaired compared with young islets when stimulated. Using a high glucose concentration (16. $7 \mathrm{mM}$ ) and the amino acids found in MEM, we found a $66 \%$ decrease in secretion of total immunoreactive insulin (largely stored, preformed insulin) and a $39 \%$ decrease in proinsulin synthesis in old islets cultured in vitro for $16 \mathrm{~h}$ in $5.5 \mathrm{mM}$ glucose.

Our findings are most readily explained by postulating defects in transduction of glucose-induced stimulatory signals to insulin secretion and synthesis in old islets (Fig. 5). Previous 


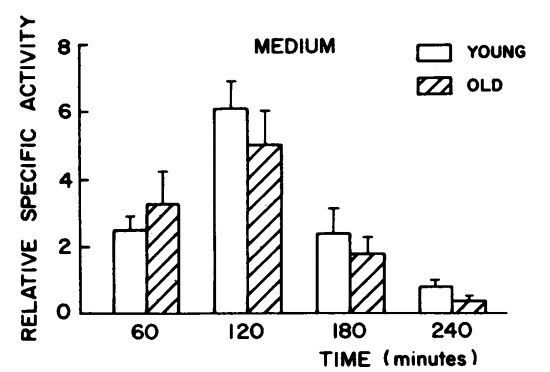

A

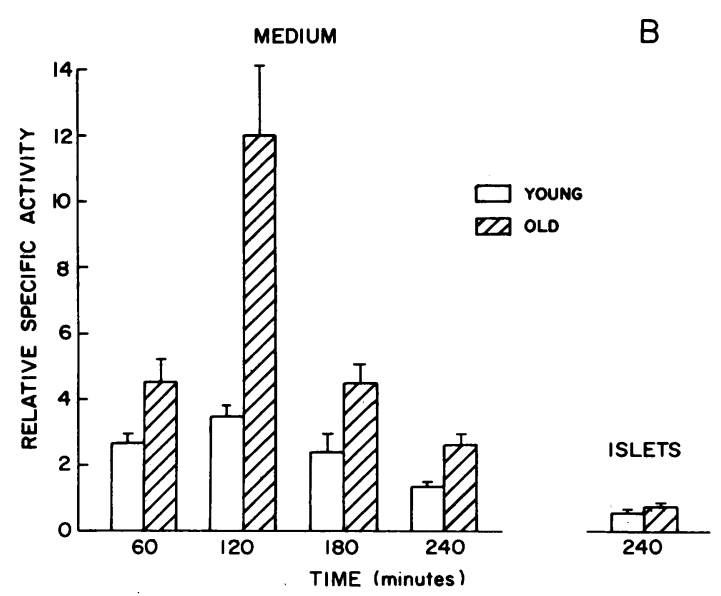

Figure 4. $(A)$ Time course of secretion of newly made insulin by 4-5and 21-22-mo islets at $2.8 \mathrm{mM}$ glucose. After preincubation for $16 \mathrm{~h}$ in MEM and a 30-min pulse label in $16.7 \mathrm{mM}$ glucose in MEM with $\left[{ }^{3} \mathrm{H}\right]$ leucine, islets were chased for $240 \mathrm{~min}$ in MEM with $2.8 \mathrm{mM}$ glucose. Aliquots of the medium were taken every $60 \mathrm{~min}$, and the relative specific activity of the secreted insulin at each time was determined, after subtracting out the contribution of previously secreted insulin. Specific radioactivity of insulin was defined as counts per minute in immunoprecipitable insulin per nanograms of total immunoreactive insulin, and relative specific radioactivity was calculated as the ratio of the specific radioactivity of secreted hormone at a given time to that of the intraislet proinsulin, expressed as equivalent amounts of insulin, after the 30 -min pulse-label period. Immunoprecipitated, secreted $\left[{ }^{3} \mathrm{H}\right]$ hormone was converted to equivalent amounts of secreted $\left[{ }^{3} \mathrm{H}\right]$ insulin by assuming that $15 \%$ of the secreted hormone was proinsulin. Measured islet insulin contents (nanograms per islet) were at the end of the pulse period, young $25.1 \pm 4.5$ and old $42.7 \pm 5.3$, and at the end of the chase period, young $31.0 \pm 4.5$ and old $43.7 \pm 2.4$. Four islet preparations were studied for each age range. $(B)$ Time course of secretion of newly made insulin by young and old islets at $16.7 \mathrm{mM}$ glucose. After a 30-min pulse label in $16.7 \mathrm{mM}$ glucose in MEM with [ ${ }^{3} \mathrm{H}$ ]leucine, islets were chased for $240 \mathrm{~min}$ in MEM with $16.7 \mathrm{mM}$ glucose. Other details are given above. At $120 \mathrm{~min}$, the difference in relative specific radioactivities between young and old islets was statistically significant $(P$ $<0.01$ ). Measured islet insulin contents (nanograms per islet) were at the end of the pulse period were, young $35.2 \pm 7.3$ and old $36.7 \pm 6.2$, and at the end of the chase period, young $37.5 \pm 6.0$ and old 37.7 \pm 7.8 . Five islet preparations were studied for each age range.

work on stimulus-secretion coupling in B cells suggests that several signals are generated by a glucose stimulus, including a signal to secrete preformed insulin stored in secretory vesicles (the initial response, which has two phases), a signal, which may be the same or different, to secrete newly made insulin, and a signal to synthesize more insulin. Our results suggest that all of these signals are affected by aging, but to varying extents.
The greatest impairment is in the signal to secrete preformed insulin. The nature of this signal has been extensively investigated. It appears to be a metabolite of glucose, at or after the level of glucokinase $(31,32)$, and before the level of the triose phosphates; since the triose glyceraldehyde stimulates insulin secretion equally well in 2- and 12 mo rat islets (29). The signal generates promoting or modulating messengers in the cyclic AMP-protein kinase A pathway, and in the phosphatidyl inositol-protein kinase $\mathrm{C}-\mathrm{Ca}^{++}$pathway $(31,32)$, which may act at distinct steps in secretion vesicle exocytosis, since trifluoperazine, an inhibitor of calmodulin, inhibits glucose-induced insulin release, but not cyclic AMP-dependent insulin release (33). Draznin et al. found that in islets from 18 mo Fischer rats, margination of secretion vesicles was decreased compared with 2 mo rats when stimulated by glucose, but not when stimulated by glyburide, suggesting that glucose stimulus-secretion coupling for preformed insulin stores was impaired, rather than the secretion pathway itself (30).

Further, our results show that the signal to secrete newly made insulin at $16.7 \mathrm{mM}$ glucose is decreased by $41 \%$ in old B cells. Because the effectiveness of the signal to secrete newly made insulin is impaired less than that causing secretion of preformed insulin, newly made insulin makes up a greater proportion of secreted insulin in old islets, as reflected by the increased specific radioactivity of secreted insulin in the pulse-chase experiments. A similar finding was made by Gold et al. (27) in comparing islets from 2 and 12 mo-old male Sprague-Dawley rats. They interpreted these results as indicating two insulin pools in B cells, a glucose-responsive pool and a total pool, as originally proposed by Grodsky (34), and that the glucose-responsive pool was decreased in size in older animals, although the results could also be explained by postulating decreased sensitivity of a pool of preformed insulin to the glucose stimulus. Others finding preferential release of newly synthesized insulin in young animals have also supported the concept of at least two pools of insulin $(35,36)$. When insulin release was stimulated by $16.7 \mathrm{mM}$ glucose or 1 $\mathrm{mM}$ 3-isobutyl-1-methylxanthine at $2.8 \mathrm{mM}$ glucose in young rats, preferential release of newly made insulin was less pronounced, suggesting differential sensitivity of the pools towards secretagogues (36). Gold et al. have postulated that in normal rat islets, secretagogues such as glucose can "mark" newly made insulin during transport through the Golgi apparatus or during formation of secretory granules, and thus cause its preferential secretion (37). If this is correct, our results would indicate that high glucose concentrations are less effective in signalling the mobilization of the preformed pool of insulin than the "marking" of the newly made pool in old islets.

Glucose also signals the B cell to synthesize insulin. As shown by Permutt, glucose stimulates insulin biosynthesis in B cells both at the translational level and the transcriptional level (38). Stimulation during a high glucose pulse is largely due to increased translation of mature preproinsulin mRNA $(38,39)$. However, Giddings et al. have shown that if the glucose stimulus is prolonged, insulin gene-specific transcription is also increased (40), an effect that may be mediated in part by cAMP (41). Also, high glucose inhibits insulin mRNA degradation (42). Comparing proinsulin biosynthesis directly in vivo in old and young animals would be desirable, but would require injection of very large amounts of radioactive amino acid to label newly made proinsulin (43), due to the great weight of 
Table V. Effects of Age on Secretion of Total Immunoreactive Insulin and ${ }^{3} \mathrm{H}$-Labeled Insulin and Protein by Islets over a 240-min Chase Period at $16.7 \mathrm{mM}$ Glucose After a 30-min Pulse-Label Period (Islets Were Preincubated for $16 \mathrm{~h}$ in MEM with $5.5 \mathrm{mM}$ Glucose)

\begin{tabular}{|c|c|c|c|c|c|}
\hline \multirow[b]{2}{*}{ Age } & \multicolumn{2}{|c|}{ Amount secreted in $16.7 \mathrm{mM}$ chase } & \multicolumn{3}{|c|}{ Secreted in $16.7 \mathrm{mM}$ chase } \\
\hline & {$\left[{ }^{3} \mathrm{H}\right] \mathrm{INS}$} & {$\left[{ }^{3} \mathrm{H}\right]$ PROT } & {$\left[{ }^{3} \mathrm{H}\right] \mathrm{INS}$} & RIA INS & {$\left[{ }^{3} \mathrm{H}\right] \mathrm{PROT}$} \\
\hline mo & cpm/ng islet insulin & cpm/ng islet insulin & $\%$ & $\%$ & $\%$ \\
\hline $4-5$ & $28.1 \pm 3.0$ & $57.1 \pm 4.6$ & $61.9 \pm 5.3$ & $29.5 \pm 2.5$ & $17.9 \pm 0.8$ \\
\hline $21-22$ & $10.1 \pm 0.8$ & $31.3 \pm 3.0$ & $36.2 \pm 2.4$ & $9.8 \pm 1.0$ & $10.9 \pm 1.5$ \\
\hline$n$ & 5 & 5 & 5 & 5 & 5 \\
\hline$P$ & $<0.01$ & $<0.01$ & $<0.01$ & $<0.01$ & $<0.01$ \\
\hline
\end{tabular}

Islets were pulse-labeled for $30 \mathrm{~min}$ in $16.7 \mathrm{mM}$ glucose with $\left[{ }^{3} \mathrm{H}\right]$ leucine, and then subjected to a 240 -min chase period in the presence of 16.7 $\mathrm{mM}$ glucose. Other details are given in the legend for Table IV.

animals at the ages studied here. Using isolated islets, we found that proinsulin synthesis was decreased in old islets compared with young islets. Since preproinsulin mRNA levels were not significantly lower in old islets, the decrease in proinsulin synthesis upon pulse glucose stimulation in old B cells is likely to be due to decreased transduction by old islets of a glucose stimulus into factors enhancing translation of preproinsulin mRNA. However, because of the relatively large standard errors in our measurements of islet preproinsulin mRNA levels (Table II), we cannot rule out the possibility that decreases in preproinsulin mRNA levels might contribute to decreased proinsulin synthesis in old islets.

It will be important to better characterize the glucose stimulus transducing steps that are impaired in islets with aging. These may not solely be in the B cell. A glucose stimulus acting on islets may induce paracrine effects, such as glucagon and somatostatin release, as well as direct effects on B cells (44),

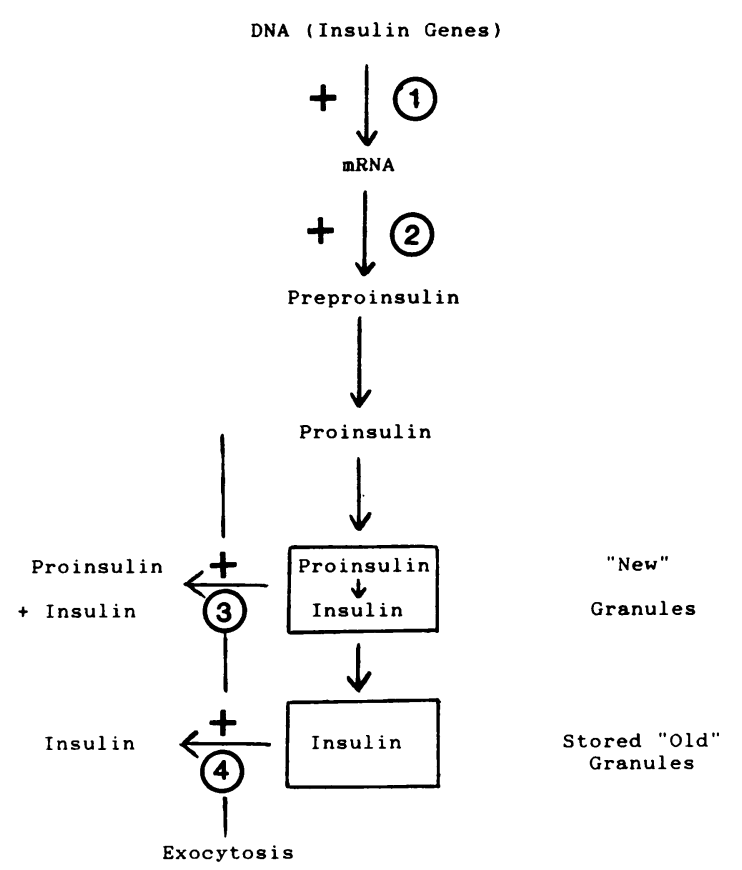

Figure 5. Pathway of glucose-stimulated insulin synthesis and secretion in B cells. Numbered arrows show steps that are stimulated by glucose. Aging has been shown to impair the effects of a glucose stimulus on steps 2,3 , and 4 . and Adelman has postulated that these effects may partially explain the differential responses of old and young islets (45). Since most of the presently postulated signals and pathways for transduction of the glucose signal, whether direct or paracrine, are amenable to direct stimulation and inhibition (31), one should be able to define specific signalling impairments that affect glucose stimulated insulin synthesis and secretion by $\mathbf{B}$ cells with aging. Presumably, more than one signal is impaired, since here we have shown differential effects of aging on glucose-stimulated B cell functions. Elucidation of these impairments may lead to general insights into changes in signalling pathways from the extracellular environment to intracellular responses with age, as well as better understanding of aging as a model of impaired glucose homeostasis.

\section{Acknowledgments}

We are indebted to William Chin for advice and guidance on the molecular biological aspects of this work, and to Peter Ronner for initial assistance with the Northern blots. We thank Dr. Goodman for the pcr(I)IN plasmid, Dr. Weir for anti-rat insulin serum, and Jeffrey Flier, Alan Moses, and Pat Usher for sharing their facilities. We thank Gail Wong for general assistance, and William Chin, Dariush Elahi, Kenneth Minaker, and Dorrie Rosenblatt for comments on the manuscript. We are grateful to Professor Eugene Bell, Department of Biology, Massachusetts Institute of Technology, in whose laboratory some of these studies were initiated.

This work was supported by National Institutes of Health (NIH) grants AG-00599 and AM-35292, and a National Institute on Aging pilot study animal grant. Dr. Wang is the recipient of NIH Academic Award AG-00345. This work was also supported, in part, by the MacArthur Foundation Research Program on Successful Aging.

\section{References}

1. Weir, G. C. 1982. Non-insulin dependent diabetes mellitus: interplay between B-cell inadequacy and insulin resistance. Am. J. Med. 73:461-464.

2. Andres, R., and J. D. Tobin. 1975. Aging and the disposition of glucose. Adv. Exp. Med. Biol. 61:239-249.

3. DeFronzo, R. 1979. Glucose intolerance and aging: evidence for tissue insensitivity to insulin. Diabetes. 28:1095-1101.

4. Fink, R. I., O. G. Kolterman, J. Griffin, and J. M. Olefsky. 1983. Mechanisms of insulin resistance in aging. J. Clin. Invest. 71:15231535.

5. Rowe, J. W., K. L. Minaker, J. A. Pallotta, and J. S. Flier. 1983. Characterization of the insulin resistance of aging. J. Clin. Invest. 71:1581-1587. 
6. Minaker, K. L., J. W. Rowe, J. Palotta, and D. Sparrow. 1982. Clearance of insulin: influence of steady-state insulin level and age. Diabetes. 31:132-135.

7. Kitahara, A., and R. C. Adelman. 1979. Altered regulation of insulin secretion in isolated islets of different sizes in aging rats. Biochem. Biophys. Res. Commun. 87:1207-1213.

8. Reaven, E., D. Wright, C. E. Mondon, R. Solomon, H. Ho, and G. M. Reaven. 1983. Effect of age and diet on insulin secretion and insulin action in the rat. Diabetes. 32:175-180.

9. Curry, D. L., G. Reaven, and E. Reaven. 1984. Glucose-induced insulin secretion by perfused pancreas of 2- and 12-month old Fischer 344 rats. Am. J. Physiol. 247:E385-388.

10. Elahi, D., D. C. Muller, D. K. Andersen, J. D. Tobin, and R. Andres. 1985. The effect of age and glucose concentration on insulin secretion by the isolated perfused rat pancreas. Endocrinology. 116:11-16

11. Chen, M., R. N. Bergman, G. Pacini, and D. Porte, Jr. 1985. Pathogenesis of age-related gluose intolerance in man: insulin resistance and decreased B-cell function. J. Clin. Endocrinol. \& Metab. 60:13-20.

12. Chirgwin, J. M., A. E. Przybyla, R. J. MacDonald, and W. J. Rutter. 1979. Isolation of biologically active ribonucleic acid from sources enriched in ribonuclease. Biochemistry. 24:5249-5299.

13. Maniatis, T., E. F. Fritsch, and J. Sambrook. 1982. Molecular Cloning: A Laboratory Manual. Cold Spring Harbor Laboratory, Cold Spring Harbor, NY. 545 pp.

14. Hayward, W. S. 1977. Size and genetic content of viral RNAs in avian oncovirus-infected cells. J. Virol. 24:47-63.

15. Ullrich, A., J. Shine, J. Chirgwin, R. Pictet, E. Tischer, W. J. Rutter, and H. M. Goodman. 1977. Rat insulin genes: construction of plasmids containing the coding sequences. Science (Wash. DC). 196:1313-1318.

16. Cordell, B., D. Diamond, S. Smith, J. Punter, H. H. Schone, and H. M. Goodman. 1982. Disproportionate expression of the two nonallelic rat insulin genes in a pancreatic tumor is due to translational control. Cell. 31:531-542.

17. Lacy, P. E., and M. Kostianovsky. 1967. Method for the isolation of intact islets of Langerhans from the rat pancreas. Diabetes. 16:35-39.

18. Scharp, D. W., C. Kemp, M. Knight, W. Ballinger, and P. E Lacy. 1973. The use of Ficoll in the preparation of viable islets of Langerhans from the rat pancreas. Transplantation (Baltimore). 16:686-689.

19. Halban, P. A., C. B. Wollheim, B. Blondel, and A. E. Renold. 1980. Long term exposure of isolated pancreatic islets to mannoheptulose: evidence for insulin degradation in the B-cell. Biochem. Pharmacol. 29:2625-2633.

20. Halban, P. A., C. J. Rhodes, and S. E. Shoelson. 1986. High performance liquid chromatography: a rapid, flexible, and sensitive method for separating islet proinsulin and insulin. Diabetologia. 29:893-896.

21. Herbert, V., K.-S. Lau, C. W. Gottlieb, and S. J. Bleicher. 1965. Coated charcoal immunoassay of insulin. J. Clin. Endocrinol. \& Metab. 25:1375-1384.

22. Fisher, R. A., and F. Yates. 1963. Statistical Tables for Biological, Agricultural and Medical Research. 6th ed. Oliver \& Boyd Ltd., Edinburgh, Scotland. $146 \mathrm{pp}$.

23. Brunstedt, J., and S. J. Chan. 1982. Direct effect of glucose on the preproinsulin mRNA level in isolated pancreatic islets. Biochem. Biophys. Res. Commun. 106:1383-1389.

24. Giddings, S. J., J. M. Chirgwin, and M. A. Permutt. 1985. Glucose regulated insulin biosynthesis in isolated rat pancreatic islets is accumpanied by changes in proinsulin mRNA. Diabetes Res. 2:71-75.
25. Giddings, S. J., J. Chirgwin, and M. A. Permutt. 1985. Evaluation of rat insulin messenger RNA in pancreatic and extrapancreatic tissues. Diabetologia. 28:343-349.

26. Rowe, J. W. 1977. Clinical Research in aging: strategies and directions. N. Engl. J. Med. 297:1332-1335.

27. Gold, G., G. M. Reaven, and E. Reaven. 1981. Effect of age on proinsulin and insulin secretory pattern in isolated rat islets. Diabetes. 32:175-180.

28. Fink, R. I., T. Hueckstedt, and Z. Karaoghlanian. 1986. The effects of aging on glucose metabolism in adipocytes from Fischer rats. Endocrinology. 118:1139-1147.

29. Molina, J. M., F. H. Premdas, and L. G. Lipson. 1985. Insulin release in aging: dynamic response of isolated islets of Langerhans of the rat to D-glucose and D-glyceraldehyde. Endocrinology. 116:821826.

30. Draznin, B., J. P. Steinberg, J. W. Leitner, and K. E. Sussman. 1985. The nature of the insulin secretory defect in aging rats. Diabetes. 34:1168-1173.

31. Hedeskov, C. J. 1980. Mechanism of glucose-induced insulin secretion. Physiol. Rev. 60:442-509.

32. Ashcroft, S. J. H. 1980. Glucoreceptor mechanisms and the control of insulin release and biosynthesis. Diabetologia. 18:5-15.

33. Steinberg, J., J. W. Leitner, B. Draznin, and K. E. Sussman. 1984. Calmodulin and cyclic AMP: possible different sites of action of these two regulatory agents in exocytotic hormone release. Diabetes. 33:339-345.

34. Grodsky, G. M. 1972. A threshold distribution hypothesis for packet storage of insulin and its mathematical modelling. J. Clin. Invest. 51:2047-2059.

35. Gold, G., H. D. Landahl, M. L. Gishizky, and G. M. Grodsky. 1982. Heterogeneity and compartmental properties of insulin storage and secretion in rat islets. J. Clin. Invest. 69:554-563.

36. Halban, P. A. 1982. Differential rates of release of newly synthesized and of stored insulin from pancreatic islets. Endocrinology. 110:1183-1188.

37. Gold, G., M. L. Gishizky, and G. M. Grodsky. 1982. Evidence that glucose "marks" B-cells resulting in preferential release of newly synthesized insulin. Science (Wash. DC). 218:56-58.

38. Permutt, M. A., and D. M. Kipnis. 1972. Insulin biosynthesis. I. On the mechanism of glucose stimulation. J. Biol. Chem. 247:1194-1199.

39. Itoh, N., and H. Okamoto. 1980. Translational control of proinsulin synthesis by glucose. Nature (Lond.). 283:100-102.

40. Giddings, S. J., J. Chirgwin, and M. A. Permutt. 1982. Effects of glucose on proinsulin messenger RNA in vivo. Diabetes. 31:624-629.

41. Nielsen, D. A., M. Welsh, M. J. Casadaban, and D. F. Steiner. 1985. Control of insulin gene expression in pancreatic B-cells and in an insulin-producing cell line, RIN-5F cells. I. Effects of glucose and cyclic AMP on the transcription of insulin mRNA. J. Biol. Chem. 260:13585-13589.

42. Welsh, M., D. A. Nielsen, A. J. MacKrell, and D. F. Steiner. 1985. Control of insulin gene expression in pancreatic B-cells and in an insulin-producing cell line, RIN-5F cells. II. Regulation of insulin mRNA stability. J. Biol. Chem. 260:13590-13594.

43. Permutt, M. A., K. Kakita, P. Malinas, I. Karl, S. Bonner-Weir, G. Weir, and S. J. Giddings. 1984. An in vivo analysis of pancreatic protein and insulin biosynthesis in a rat model for non-insulin-dependent diabetes. J. Clin. Invest. 73:1344-1350.

44. Samols, E., S. Bonner-Weir, and G. C. Weir. 1986. Intra-islet insulin-glucagon-somatostatin relationships. Clinics Endocrinol. \& Metab. 15:33-58.

45. Chaudhuri, M., J. L. Startin, and R. C. Adelman. 1983. A role for somatostatin in the impaired insulin secretory response to glucose by islets from aging rats. J. Gerontology. 38:431-435. 